\title{
Immunosuppressive Drugs as a Tool to Explore Immunopathology in Experimental Chagas Disease
}

\author{
KS Calabrese
}

\begin{abstract}
Laboratório de Imunomodulação, Departamento de Protozoologia, Instituto Oswaldo Cruz, Av. Brasil 4365, 21045-900 Rio de Janeiro, RJ, Brasil
\end{abstract}

Key words: Chagas disease - immunopathology - cardiomyopathy

Chagas disease is a parasitic infection, and its main manifestations are the cardiac and digestive forms. In the chronic cardiac form, on a significant number of cases, a severe cardiomyopathy is developed. A therapeutic alternative in the Chagas disease evolution of a patient with terminal chronic chagasic myocarditis could be the rehabilitation through a cardiac transplantation (Boullon et al. 1988). These patients are submitted to immunosuppressive therapy in order to prevent graft rejection (Bocchi 1987, Stolf et al. 1987, Almeida et al. 1996).

Over the last years, new aspects have surfaced through the association of Chagas disease with the acquired immunodeficiency syndrome (Aids) (Del Castillo et al. 1990, Gluckstein \& Silva 1992, Oddo et al. 1992, Rocha et al. 1994, Ferreira et al. 1997). Chagas disease in immunocompromissed hosts is not exclusively associated to Aids, but also to the action of immunosuppressive drugs that are applied in cancer and transplant chemotherapy (Bocchi 1987, Jatene 1987, Stolf et al. 1987, Uip et al. 1987).

After an acute phase of Chagas disease in which a "clinical cure" is obtained through chemotherapy or in assymptomatic cases, the parasite/host relationship is disturbed only when a treatment with immunosuppressive drugs is introduced. It has been demonstrated that immunosuppressive drugs can modulate both cell mediated immunity and antibody production, thus affecting concomitant immunity (or premunition). On the other hand, when some immunosuppressive drugs are given before infection they may promote an enhancement of cell mediated immunity and, paradoxaly, induce resistance against facultative intracellular parasites (Tripathy \& Mackaness 1969, Gonçalves da Costa \& Lagrange 1981).

Fax: +55-21-598.4323.

E-mail: calabres@gene.dbbm.fiocruz.br

Received 9 June 1999

Accepted 9 August 1999
In the past, cyclophosphamide (CY) was used in the immunosuppressive therapy for the cardiac transplant. At this moment, the most used therapy is a treatment schedule formed by cyclosporin A (CsA), azatioprin and a corticoid (Ferraz \& Figueiredo 1993).

Experimental use of immunosuppressive drugs demonstrated that CY injected after Trypanosoma cruzi infection induces an enhancement of myocarditis (Kumar et al. 1970). This was confirmed by Andrade et al. (1987) in dogs as well as in mice by Calabrese et al. (1987) and Silva and Rossi (1990).

The action of this drug is dose and time dependent as observed in a experimental schedule using high dose of CY before or after infection with $T$. cruzi $\mathrm{Y}$ strain. Mice treated by a single dose of $200 \mathrm{mg} / \mathrm{kg}$ of CY two days before infection had a first parasitaemic peak on day five which was higher than the control group. After that, the course of the infection was similar to the infected nontreated control group. On the other hand, mice treated five days after infection with the same dose displayed a constant and higher ascendant parasitaemia. Animals treated with therapeutic doses $(3 \mathrm{mg} / \mathrm{kg})$ show the same result as mice treated with high dose five days after infection.

The analysis of blood cells, on animals treated five days after infection showed waves of leukocytes with a reduced number of cells on the 8th day after infection, the day of the parasitaemia peak of the Y strain. This justifies a small number of cells in inflammatory infiltrate on the heart on day 12 after infection. As CY is a cytotoxic drug, at this time the cells are suppressed. However the group treated two days before infection showed a great inflammatory infiltrate on the heart according to the great number of leukocytes circulating on blood because the toxic effect had already finished. The results of therapeutic doses $(3 \mathrm{mg} / \mathrm{kg})$ showed a great number of circulating leukocytes.

The specific analysis of these cells in the blood showed an enhancement of polymorphonuclear and monocytes cells seven days after the injection of the drug on animals treated two days before infec- 
tion with a single dose of $200 \mathrm{mg} / \mathrm{kg}$. The same was observed with therapeutic doses.

In summary, the treatment with $\mathrm{CY}$ in mice expresses a polarity that is characterized by: (1) an enhancement of the inflammatory reaction and a consequent control of parasite proliferation in the myocardium of mice treated with a dose of 200 $\mathrm{mg} / \mathrm{kg}$ two days before the infection in one pole; (2) a low inflammatory infiltrate associated with a high parasite burden when $\mathrm{CY}$ is given five days after infection on the other pole (Calabrese et al. 1996).

In the 60's, Sandoz laboratories extracted an undecapeptide from the fungus Tolipocladium inflatum Gam, which was named CsA (Petcher et al. 1976, Ruegger et al. 1976, Borel \& Robert 1989). The advent of CsA as an immunosuppressive drug in the early 80 s revolutionized the field of clinical transplantation by altering the degree and specificity of immunosuppressive therapy. This drug exerts its primary influence on CD4+T (helper) cells, with indirect effects on other leukocyte populations. It suppresses IL-2 production and reduces the IFN $\gamma$ (production occurs in a dose-dependent way). This effect on IFN $\gamma$ production may explain the reduced activity of natural killer (NK) cells that can be observed during CsA treatment (Borel \& Wiesinger 1979).

The action of CsA on parasitic infections has been intensively studied. It was reported that Plasmodium growth in vitro was inhibited by the drug (Nickell et al. 1982) and it was effective in clearing parasitaemia in both rodent and monkey malaria (Cole et al. 1983). It has been also effective against helmintic infections as Strongyloides and Schistosoma mansoni infections in rats and immunodeficient mice too (Bueding et al. 1981, Schad 1986, Bout et al. 1986). The in vitro multiplication of $T$. cruzi epimastigotes was inhibited by CsA, but not the intracellular replication of amastigotes. Nevertheless it has been reported that CsA exacerbates the time course infection of T. cruzi in outbred as well as inbred Balb/c mice (McCabe et al. 1985).

CsA results did not show the same pattern obtained with CY. The animals treated with $20 \mathrm{mg} /$ $\mathrm{kg}$ of CsA either two days before or five days after T. cruzi $\mathrm{Y}$ strain infection did not show any significant difference on histhological analysis. When we analyzed the circulating leukocytes on blood the bipolar effect observed in mice treated with CY was not observed in CsA treated ones. In the addition, we also have not observed the alternate pattern of leukopenia/leukocytosis observed in control infected non-treated mice. Mice CsA treated with a single dose of $200 \mathrm{mg} / \mathrm{kg}$ five days after infection presented less cells than infected non-treated control mice on day 12 of infection course. Animals treated with therapeutic doses of $10 \mathrm{mg} / \mathrm{kg}$ maintained the leukocyte number values.

Differential cell counts showed a modulatory effect of CsA $200 \mathrm{mg} / \mathrm{kg}$ administered five days after infection upon leukocytes. The drug neutralizes the suppression provoked by $T$. cruzi on polymorphonuclear cells and aggravate the normally depressed number of monocytes on the 9th day after infection. Neither therapeutic doses nor a high single dose of $200 \mathrm{mg} / \mathrm{kg}$ administered two days after infection have shown significant results.

Parasitaemia of CsA treated animals was higher than the one observed in infected non-treated control animals. The number of parasites on groups treated with $200 \mathrm{mg} / \mathrm{kg}$ two days before infection was the same found on those treated with therapeutic doses. Groups treated two days before infection with $200 \mathrm{~m} / \mathrm{kg}$ showed parasitaemia two times higher than control animals.

Histological analysis of animals treated with any doses of CsA on day 12 after infection showed no difference between them. A moderate to intense diffuse inflammatory infiltrate exhibiting mononuclear cells was observed in the heart. Striated muscle cells appeared colonized by amastigotes but there was not any significant difference when compared with the infected non-treated control group.

The role played by T-cells in a $T$. cruzi infection is still a controversial subject. It is known that the depletion of T-cells exacerbates the course of T. cruzi infection. Trischmann $(1983,1984)$ suggested that T-cells exert an anti-parasite effect that precedes the antibody response and is independent of this response. Gonçalves da Costa et al. (1984), in a study using athymic nude mice (nu/nu) infected with $T$. cruzi, have shown an enhancement of the parasitaemia and tissue colonization among these mice, in contrast with their heterozygous littermates $(\mathrm{nu} /+)$ in which the parasitaemia remained at lower levels. A drastic systemic colonization was observed in almost all tissues and organs without an inflammatory reaction, but $\mathrm{T}$-cell transfer restored it. Russo et al. (1988) have shown that, by inactivating $\mathrm{T}$ helper-cells in chagasic $\mathrm{C} 3 \mathrm{H}$ mice, blood and tissue parasite load have been increased whereas, at the same time, there was a reduction of the cellular infiltrate in the heart.

These results suggest that CD4+ T-lymphocytes play a dual role in the immunopathology of acute experimental Chagas disease, modulating the pathogenesis and host resistance to T. cruzi (Russo et al. 1988). Hontebeyrie-Joskowicz et al. (1987) have adopted the same approach, since CD4+ Tlymphocytes from chronically infected mice are able to develop a Chagas disease-like pathology in non-infected mice. 
In parallel, it has also been reported that CD8+ T-cells play a role in the acute phase of experimental Chagas disease by enhancing parasitaemia and mortality. These results were obtained through the depletion of CD8+ T-cells in both resistant and highly susceptible mice strains infected with the Brazil strain of T. cruzi (Tarleton 1990).

A characterization of the cellular infiltrate is essential for a better understanding of the immunopathogenesis of experimental Chagas disease.

Immunohistochemical analysis by confocal microscopy of the inflammatory reaction in heart has shown that macrophages are a major component of the inflammatory infiltrate in all groups of CsA treated mice and also in the control group. The results suggest that high dose of CsA can block the activation of macrophages completely and that it allows parasite multiplication.

Investigations have been done to better understand the mechanism of action of this immunosuppressive drugs in experimental Chagas disease

\section{REFERENCES}

Almeida DR, Carvalho AC, Branco JN, Pereira AP, Correia L, Vianna PV, Buffolo E, Martinez EE 1996. Chagas disease reactivation after transplantation: efficacy of allopurinol treatment. J Heart Lung Transplant 15: 988-992.

Andrade ZA, Andrade SG, Sadigursky M 1987. Enhancement of chronic Trypanosoma cruzi myocarditis in dog treated with low doses of cyclophosphamide. Am J Pathol 127: 467-473.

Bocchi EA 1987. Imunossupressão na doença de Chagas. Aspectos clínicos-cardiológicos na imunossupressão. Rev Soc Bras Med Trop 20: M39-40.

Borel JF, Robert O 1989. La ciclosporine. La Recherche 20: 763-711.

Borel JF, Wiesinger D 1979. Studies on the mechanism of action of cyclosporin A. Br J Pharmacol 66: 66P67P.

Boullon F, Sinagra A, Riarte A, Lauricella M, Barra J, Besanson M, Lejour C, Lopez Blanco O, Favaloro R 1988. Experimental cardiac transplantation and chronic Chagas disease in dogs. Transp Proc 20: 432437.

Bout DT, Deslée D, Capron AR 1986. Antischistosomal effect of cyclosporine A: cure and prevention of mouse and rat schistosomiasis mansoni. Infect Immun 52: 823-827.

Bueding E, Hawking J, Cha YN 1981. Antischistosomal effects of cyclosporine A. Agents Actions 11: 380383.

Calabrese KS, Bauer PG, Gonçalves da Costa SC 1987. Evolution and distribution of Trypanosoma cruzi in some organs of cyclophosphamide treated mice. Mem Inst Oswaldo Cruz 82: 47.

Calabrese KS, Lagrange PH, Gonçalves da Costa SC 1996. Chagas disease: enhancement of systemic inflammatory reaction in cyclophosphamide treated mice. Int J Immunopharmacol 18: 505-514.

Cole GA, Nickell SP, Mokhtarian F, Scheibel LW 1983. Effects of cyclosporine on experimental infections. Transplant Proc 15: 2271-2277.

Del Castillo M, Mendoza G, Oviedp J, Bianco RPP, Anselmo AE, Silva M 1990. AIDS and Chagas disease with central nervous system tumor-like lesion. Am J Med 88: 693-694.

Ferraz AS, Figueiredo JFC 1993. Transmission of Chagas disease through transplanted kidney: occurence of the acute form of the disease in two recipients from the same donor. Rev Inst Med Trop São Paulo 35: 461-463.

Ferreira MS, Nishioka SA, Silvestre MT, Borges AS, Nunes-Araujo FR, Rocha A 1997. Reactivation of Chagas disease in patients with AIDS: report of three new cases and review of the literature. Clin Infect Dis 25: 1397-1400.

Gluckstein D, Silva M 1992. Chagas disease: another cause of cerebral mass in AIDS. Am J Med, 96: 301302.

Gonçalves da Costa SC, Lagrange PH 1981. Development of cell mediated immunity to flagellar antigens and acquired resistance to infection by Trypanosoma cruzi in mice. Mem Inst Oswaldo Cruz 76: 367-381.

Gonçalves da Costa SC, Lagrange PH, Hurtrel B, Kerr I, Alencar AA 1984. Role of T Lymphocytes in the resistance and immunopathology of experimental Chagas disease I - Histopathological studies. Ann Immunol (Inst Pasteur) 135 C: 317-332.

Hontebeyrie-Joskowicz M, Minoprio P 1996. Chagas disease: Trypanosoma cruzi vs. the host immune system. Inst Pasteur Elsevier 142: 125-181.

Jatene AD 1987. Transplante de coração em pacientes com miocardiopatia chagásica. Rev Soc Bras Med Trop 20: C5-6.

Kumar R, Kline IK, Walter AH 1970. Immunosupression in experimental acute and subacute chagasic myocarditis. Am J Trop Med Hyg 19: 932-939.

McCabe RE, Remington JS, Araujo FG 1985. In vivo and in vitro effects of cyclosporin A on Trypanosoma cruzi. Am J Trop Med Hyg 34: 861-865.

Nickell SP, Scheibel LW, Cole GA 1982. Inhibition by cyclosporin A of rodent malaria in vivo and human malaria in vitro. Infect Immun 37: 1093-1100.

Oddo D, Casanova M, Acuma G, Ballesteros J, Morales B 1992. Acute Chagas disease (trypanosomiasis Americana) in acquired immunodeficiency syndrome: report of two cases. Hum Pathol 23: 41-44.

Petcher TJ, Weber HP, Ruegger A 1976. Cristal and molecular structure of an iodo-derivate of the cyclic endecapeptide cyclosporin A. Hel Chim Acta 59: 1480-1489.

Rocha A, Meneses CA, da Silva AM, Ferreira MS, Nishioka SA, Burgarelli MK, Almeida E, Turcato Junior G, Metze K, Lopes ER 1994. Pathology of patients with Chagas disease and acquired immunodeficiency syndrome. Am J Trop Med Hyg 50: 261268.

Ruegger A, Kuhn M, Lichti H, Loosli HR, Huguenin R, Quiquerez C, von Wartburg A 1976. Cyclosporin A. Ein immunosuppresiv wirkamer Peptidmetabolit aus Tricoderma polysporium (Link ex Pers). Rafai 
Helv Chim Acta 59: 1075-1092.

Russo M, Starobinas N, Minoprio P, Coutinho A, Hontebeyrie-Joskowicz M 1988. Parasitic load increase and myocardial inflammation decreases in Trypanosoma cruzi infected mice after inactivation of helper T cells. Ann Inst Pasteur/Immunol 139: 225-236.

Schad GA 1986. Cyclosporine may eliminate the threat of overhelming strongyloidiasis in immunosuppressed patients. J Infect Dis 153: 178.

Silva, JS, Rossi, MA 1990. Intensification of acute Trypanosoma cruzi myocarditis in balb/c mice pretreated with low doses of cyclophosphamide or gamma irradiation. Int J Exp Path 71: 33-39.

Stolf NAG, Higush L, Bocchi E, Bellotti G, Auler JOC, Uip D, Neto A, Pileggi F, Adib DJ 1987. Heart transplantion in patients with Chagas disease cardiomiopathy. J Heart Transpl 6: 307-312.
Tarleton R 1990. Depletion of CD8 cells increases susceptibility and reverses vaccine-induced immunity in mice infected with Trypanosoma cruzi. J Immunol 144: 717-724.

Tripathy SP, Mackaness GB 1969. The effect of cytotoxic agents on the primary immune response to Listeria monocytogenes. J Exp Med 130: 1-16.

Trischmann TM 1983. Non-antibody mediated control of parasitaemia in acute experimental Chagas disease. J Immunol 130: 1953-1957.

Trischmann TM 1984. Role of cellular immunity in protection against Trypanosoma cruzi in mice. Parasite Immunol 6: 561-570.

Uip DE, Strabelli TMV, Belotti G, Bocchi EA, Stolf N, Pileggi F, Jatene AD, Amato Neto V 1987. Evolução clínica de pacientes com doença de Chagas submetidos a transplante cardiaco. Rev Soc Bras Med Trop 20: 26. 